UDC 614.39

DOI: $10.21668 /$ health.risk/2021.1.18.eng

Review

\title{
REGULATION OF WORK-RELATED AND OCCUPATIONAL IMPACTS ON WORKERS EMPLOYED AT RAILROADS: EXPERIENCE GAINED IN RUSSIA AND OTHER COUNTRIES
}

\author{
V.A. Loginova ${ }^{1}$, Yu.N. Kas'kov ${ }^{1}$, E.A. Zhidkova ${ }^{2,3}$, K.G. Gurevich ${ }^{3}$, \\ Yu.L. Smertina ${ }^{4}$, O.A. Pletnikova ${ }^{4}$ \\ ${ }^{1}$ Federal Service for Surveillance over Consumer Rights Protection and Human Wellbeing, Railway transport \\ office, 17 Dubininskaya Str., Moscow, 115054, Russian Federation \\ ${ }^{2}$ The Central Healthcare Office, a brunch of «Russian Railways» JSC, 52a Malaya Gruzinskaya Str., Moscow, \\ 123557, Russian Federation \\ ${ }^{3}$ A.I. Yevdokimov Moscow State University of Medicine and Dentistry, 20/1 Delegatskaya Str., Moscow, 127473, \\ Russian Federation \\ ${ }^{4}$ Center for Hygiene and Epidemiology at railway transport, 2 the $1^{\text {st }}$ Basmanniy lane, Moscow, 105066, \\ Russian Federation
}

The present research is vital as it will allow increasing safety of working conditions for workers employed at railway transport due to reducing impacts exerted by occupational risk factors.

Our research goal was to perform comparative analysis of requirements to labor protection provided for railway workers.

Our research was performed via non-systemic analysis of literature that involved searching through Elibrary, Pubmed and Cochrane databases as per certain key words.

As a result, we showed that railway traffic involved exposure to numerous occupational risk factors; due to it, a significant number of workplaces, including those of enginemen and other railway workers, belonged to the $3^{\text {rd }}$ (adverse) hazard category. Basic occupational risk factors included noise and vibration; psychoemotional loads borne by engine team workers and traffic controllers; exposure to industrial aerosols; electromagnetic irradiation; fluctuations in microclimatic parameters in engines' cabs. All these occupational factors influence not only workers who are directly employed at railways but also people who live in close proximity to them. Therefore, in most countries there is legislative basis on health protection for people who may be exposed to occupational factors related to railway traffic. Our analysis revealed that in general the existing legislation in Russia corresponded to foreign one. Bases for harmonization of the domestic legislation with foreign one are fixed by the Federal Law issued on December 27, 2002 No. 184-FZ "On technical regulation”.

Harmonization of domestic and foreign legislation on reducing total exposure to occupational risk factors allows preserving long-term working ability and preventing work-related diseases.

Key words: occupational risk factors, railway transport, preventive medicine, engine team, health protection, noise, vibration, microclimate, electromagnetic irradiation.

Modern economy can't develop without railways since they are among the largest passenger and cargo transporters. Railways have made a substantial contribution into prospering

economy in many countries and are among the most beneficial means of transport that can be used regardless of a season and weather conditions. Low transportation costs are their great-

(c) Loginova V.A., Kas'kov Yu.N., Zhidkova E.A., Gurevich K.G., Smertina Yu.L., Pletnikova O.A., 2021

Vera A. Loginova - Deputy supervisor (e-mail: va-loginova@mail.ru; tel.: +7 (495) 633-27-19; ORCID: https://orcid.org/00000001-8852-2898).

Yurii N. Kas'kov - Supervisor (e-mail: kaskov.mps@bk.ru; tel.: +7 (499) 235-25-72; ORCID: https://orcid.org/00000001-2345-6789).

Elena A. Zhidkova - Supervisor, lecturer (e-mail: genmedc@gmail.com; tel.: +7 (499) 262-56-34; ORCID: https://orcid.org/00000002-6831-9486).

Konstantin G. Gurevich - Doctor of Medical Sciences, Professor, Head of the Department (e-mail: kgurevich@mail.ru; tel.: +7 (495) 681-88-31; ORCID: https://orcid.org/0000-0002-7603-6064).

Yuliya L. Smertina - Chief physician (e-mail: zamfbuz@mail.ru; tel.: +7 (495) 607-44-63; ORCID: https://orcid.org/00000003-4142-4232).

Oksana A. Pletnikova - Deputy to the Head of the Department for Operational Organization and Statistic Provision (e-mail: zamfbuz@mail.ru; tel.: +7 (495) 607-44-63; ORCID: https://orcid.org/0000-0003-4471-6070). 
est advantage since they are approximately 3 times lower than motor transport ones. Railway transport is a relatively energy-efficient mean of transportation [1].

At the same time, railway traffic involves several occupational risk factors; due to them significant number of workplaces including those of engine team workers and other railway-related occupations belong to the third hazard category, class 3.1 and 3.2 [2]. Most common adverse factors are noise, vibration, psychoemotional loads borne by engine team workers and traffic controllers, exposure to occupational aerosols, predominantly chemical ones, electromagnetic radiation, changing microclimatic parameters in engine cabins, etc. ${ }^{1}[3]$.

All the above-mentioned occupational factors exert their influence not only on people who directly work at railways but also on people who live in close proximity to them. Therefore, there are health protection programs in most countries in the world that are to protect health of people who can in this or that way be exposed to railways-related occupational factors. Such programs are aimed at reducing occupationally induced damage to health of workers and/or people who live in close proximity to railways. However, given common goals, there are discrepancies in approaches accepted in different countries regarding both control over exposure to railwayrelated occupational factors and prevention of their negative effects.

Our research goal was to perform comparative examination of world experience in regulating occupationally-induced effects produced by railways on a human body. Publications on the chosen subject are reviewed sequentially for different occupational risk factors.

Data and methods. We performed nonsystemic analysis of literature using Elibrary, Pubmed and Cochrane databases via searching keywords either in Russian or English. Search depth was not preset; our chosen keywords were railways and railway transport, as well as occupational risk factors (noise, vibration, electromagnetic radiation, and microclimate). Morphologic changes in a word base or use of a synonym were allowed. We included only full-text articles into our review. In case authors published several similar works, we took only the latest one.

Results and discussion. Noise. "Acoustics-Estimation of noise-induced hearing loss» ${ }^{2}$, ISO 1999:2013 standard, is a basic international document that determines recommended noise exposure for workers; it was last reviewed in 2018 and therefore is still valid. It was issued to replace ISO 1999:1990 «Acoustics-Determination of occupational noise exposure and estimation of noise-induced hearing impairment» ${ }^{3}$. A similar standard that is valid in the RF is GOST R ISO 1999-2017 "Acoustic. Assessing hearing loss due to exposure to noise ${ }^{4}$. The standard contains data on statistic correlations between exposure to noise and «a constant shift in hearing threshold caused by noise». The standard also includes procedures for assessing hearing loss for different categories of people taking their age into account including occupational noiseinduced hearing loss. In literature certain issues are discussed that focus on a possibility to apply the standard for making objective assessment of exposure to noise existing in an engine cabin [4].

\footnotetext{
${ }^{1}$ On the sanitary-epidemiologic situation in railway transport in 2018: The state report. Moscow, Rospotrebnadzor's Railway Transport Office, 2019, 56 p. (in Russian).

${ }^{2}$ ISO 1999:2013 «Acoustics - Estimation of noise-induced hearing loss». ISO: International Organization for Standardization. Available at: https://www.iso.org/home.html (09.08.2020) (in Russian).

${ }^{3}$ ISO 1999:1990 «Acoustics - Determination of occupational noise exposure and estimation of noise-induced hearing impairment». ISO: International Organization for Standardization. Available at: https://www.iso.org/standard/6759.html (09.08.2020) (in Russian).

${ }^{4}$ GOST R ISO 1999-2017. Acoustic. Assessing hearing loss due to exposure to noise. KODEKS: an electronic fund for legal and reference documentation. Available at: http://docs.cntd.ru/document/1200157242 (09.08.2020) (in Russian).
} 
Here we should note that occupational noise-induced hearing loss is detected in approximately $37 \%$ of adult employable population all over the world. $97 \%$ of people who suffer from this disorder are males. As a rule, the disease develops without any symptoms or with very few ones. Despite there are research works on the matter, occupational associations in foreign countries, as a rule, pay very little attention to protecting workers' acoustic organs [5]. For example, in the USA up to $10 \%$ age-related hearing problems are considered to be caused by exposure to noise [6]. Sensorineural hearing loss is thought to be the most widely spread occupationallyinduced disease among railway transport workers, first of all, enginemen and their assistants [7-9]. It has been proven that excessive exposure to noise does not only result in hearing loss in future but also leads to mistakes during work being much more probable. And such mistakes can even result in preemergency or emergency [10].

Basically noise caused by trains and their movement is related to overall feeling of unease, discomfort, and irritation that are detected both in railway workers and people living in close proximity to it [11]. Apart from hearing disorders, exposure to noise increases risks of cardiovascular diseases, neurological diseases, and gastric diseases [12, 13]. A person who is exposed to loud noise can't concentrate properly, gets tired rapidly, and consumes more calories with food [14, 15].

We should note that most research works that were accomplished in western countries and focused on impacts exerted by noise on health dealt with this problem among musicians, builders, and agricultural workers [16]. In the RF, workers employed by «Russian Railways» PLC account for approximately $1 \%$ of the total employed population; builders, $7.3 \%$; agricultural workers, $5.8 \%$ (as per data taken from rzd.ru and gsk.ru web-sites on August 09, 2020).

In the RF, Rospotrebnadzor is a competent organization responsible for assessing exposure to occupational risk factors [17]. The existing regulatory documents fix maximum permissible noise level (MPL) at $80 \mathrm{dBA}$.

Meanwhile, exposure to noise in an engine cabin can reach $92 \mathrm{~dB}$ even in developed countries and it is louder than a gunshot $(87-89 \mathrm{~dB})$. The authors of the cited study recommend using protective equipment for enginemen's acoustic organs [18]. Over recent years, there is a trend in developed countries for resolving noise-related issues via engine park modernization. New engines are constructed with up-to-date suspension, sound insulation systems, etc. In the Western Europe special attention is paid to assessing technical condition of any vehicle, including noise it makes [19]. Therefore, attention is paid to examining noise generation, noise sources detection, noise suppression and insulation, etc. [20]. A study performed in Norway in 2013 initially didn't reveal more frequent hearing loss in modern engine drivers in comparison with people from other occupational groups [21]. However, later the authors showed that there was significant hearing loss among engine team workers older than 45 in comparison with people from other occupational groups; this loss was detected for $3-5 \mathrm{kHz}$ frequencies and $3-5 \mathrm{~dB}$ intensity [22].

In a research work accomplished in the USA, it was detected that noise level in an engine cabin depended on a year an engine was put into operation, its technical condition, as well as an engine type (electric, diesel, etc.) [23]. In Canada noise levels in engine cabins were measured for different railway routes. It was shown that in summer average noise level $(88 \mathrm{~dB})$ was higher than in winter $(84 \mathrm{~dB})$. Noise level was higher than $85 \mathrm{~dB}$ in $59 \%$ of all examined cabins and it was even higher than $90 \mathrm{~dB}$ in $13 \%$ [24]. We should note that recently impacts on engine team workers' health under discussion have not been only those exerted by highly intense sounds but also infrasound and the role the latter plays in health disorders is extremely difficult to examine [25]. Besides, railway landscapes also exert their 
influence on occurrence of diseases that are caused by railways noise. Thus, tunnels make hearing loss occurrence more probable. Another issue being discussed at the moment is probable impacts exerted on enginemen's health by noise shields [26].

We should note that engine park is also being modernized in the RF at the moment. A number of engine cabins with conditions inside them being unfavorable as per noise is decreasing but still engine park modernization is far from being completed ${ }^{5}$. Besides, «Russian Railways» PLC also uses retro-trains and their engines can't be modernized.

Foreign authors tend to consider exposure to noise as a basic factor causing diseases not only among railway workers but also people who live or work in close proximity to railways [27-31]. For example in Norway hearing loss was detected among people who directly maintained railway beds [32]. A retrospect study on railway workers' audiograms performed in the USA and Europe revealed that $63 \%$ workers were regularly exposed to noise equal to $75-90 \mathrm{~dB}$. $31 \%$ people who are exposed to such noise levels suffer from hearing loss in future within $4 \mathrm{kHz}$ range, and men tend to have such disorders more frequently than women [33].

In our opinion, regulation over effects produced by noise on railway workers requires further development. First of all, it is necessary to take into account duration of exposure during working hours and rest. Besides, at present impacts exerted by noise are being examined in standardized conditions. Meanwhile, railway bed condition, tunnels, and constructions located in close proximity to railways as well as some other factors can change parame- ters of exposure to noise. Therefore, it is necessary to develop procedures for assessing exposure to noise during switching and line movement.

Vibration. On international level, impacts exerted by vibration on a human body are determined in accordance with ISO 2631-1: $1997^{6}$, the similar document that is valid in the RF is GOST 31191.1-2004 (ISO 2631-1: 1997) «Vibration and shock. Measuring overall vibration and assessing its effects on a human body» ${ }^{7}$. However, contemporary research works reveal that this standard does not fully take into account overall impacts exerted by vibration on a human body especially when this vibration is related to spatial moving [34].

Standardized vibration MPL is $112(\mathrm{Zo})$ 115 (XoYo) dB. Up to $12 \%$ of engine cabins in the RF do not correspond to hygienic standards as per vibration; and here vibration exceeds MPL by 2 times in $87 \%$ cases and by 2-3 times in 30\% cases [35]. Given excessive noise and vibration, working conditions at most enginemen's workplaces belong to 3.1 and 3.2 hazard categories [36]. Meanwhile, there are practically no studies accomplished in developed countries that would focus on examining vibration levels in an engine cabin. Exposure to vibration for an engineman is believed to be reduced via a specifically designed seat with proper ergonomics and vibration-absorbing elements [37]. However, a small comparative study didn't reveal any significant influence exerted by technical modernization on how workers subjectively perceived effects produced by vibration on their bodies [38]. At the same time it was shown that non-optimal ergonomics at a workplace did not only caused higher risks that the vibra-

\footnotetext{
${ }^{5}$ Yu.V. Pronnikov. Updating vibroacoustic calculation procedures and engine cabins design: Abstract of the thesis ... for the Candidate of Technical Sciences degree. Rostov-na-Donu, 2012, 18 p. (in Russian).

${ }^{6}$ ISO 2631-1:1997. Mechanical vibration and shock - Evaluation of human exposure to whole-body vibration Part 1: General requirements. ISO: International Organization for Standardization. Available at: https://www. iso.org/ru/standard/7612.html (09.08.2020) (in Russian).

${ }^{7}$ GOST 31191.1-2004 (ISO 2631-1:1997). Vibration and shock. Measuring overall vibration and assessing its effects on a human body. KODEKS: an electronic fund for legal and reference documentation. Available at: http://docs.cntd.ru/document/1200060904 (09.08.2020) (in Russian).
} 
tion disease might occur but also resulted in greater number of complaints from enginemen about pains in the neck, lumbar spine, etc. [39]. Excessive vibration can also lead to overall health deterioration [40].

However, vibration level in an engine cabin depends not only on its design but also railway bed condition and engine speed (measurements taken in the same engine cabin under different movement modes can yield different results). It was proven that when speed exceeded $70 \mathrm{~km} /$ hour, most technical devices that should absorb vibration do not accomplish their task completely [41]. Besides, vibration in an engine cabin can also depend on a train length, its overall mass, and some other external factors $[42,43]$. Exposure to vibration also changes depending on a posture an engineman has to maintain (sitting or standing) [44].

There are also data on long-term exposure to vibration, even within MPL limits, can result in occupationally-induced vitamin D and testosterone deficiency in enginemen $[45,46]$. Such hormonal disorders may be an additional risk factor that causes occurrence or more rapid development of cardiovascular diseases among engine team workers [47]. Recently it has been reported that vibration produces certain effects on the cardiac muscle contractibility regardless of other risk factors being present or absent. These effects can be mediated via the autonomous nervous system [47]. When vibration in an engine cabin was modeled in laboratory conditions, it was accompanied with the sympathetic nervous system activation that resulted in drowsiness [48].

Elevated risks of pains in the lumbar spine, neck, and knee were detected for work- ers who maintained railway beds; these risks were related to vibration caused by moving trains [49]. Another issue under discussion is a possibility that vibration might influence passengers' health [50].

Besides, vibration that occurs due to train movement can influence proper operation of seismological stations or stability of capital constructions located in close proximity to railways [51, 52].

We should note that regulation over impacts exerted by vibration on an engineman both in Russia and abroad involves using standardized conditions. As it is clear from the data given above, actual conditions in which engines are used can yield different results. Besides, duration of exposure to vibration has great significance even if this vibration is within MPL limits. This fact should also be taken into account in future studies and in developing new standards.

Electromagnetic exposure. Standards for safe electromagnetic exposure for a human body differ greatly in different countries. In the RF electromagnetic radiation produced by railways is regulated by requirements fixed in the SER 2.2.4.3359-16 «Sanitary-epidemiologic requirements to physical factors at workplaces» ${ }^{8}$, SER 2.2.4.1191-03 «Electromagnetic fields at workplaces»" ${ }^{9}$, SNR 2971-84 «Sanitary norms and rules for protecting population from exposure to electromagnetic fields created by air transmission lines that transmit alternating current with industrial frequency» ${ }^{10}$ and GOST 12.1.045-84 «Electrostatic fields. Permissible levels at workplaces and requirements to control activities» ${ }^{11}$. Besides, it is necessary

\footnotetext{
${ }^{8}$ SER 2.2.4.3359-16. Sanitary-epidemiologic requirements to physical factors at workplaces. KODEKS: an electronic fund for legal and reference documentation. Available at: http://docs.cntd.ru/document/420362948 (09.08. 2020) (in Russian).

${ }^{9}$ SER 2.2.4.1191-03. Sanitary-epidemiologic requirements to physical factors at workplaces. KODEKS: an electronic fund for legal and reference documentation. Available at: http://docs.cntd.ru/document/901853847 (09.08.2020) (in Russian).

${ }^{10}$ SNR 2971-84. Sanitary norms and rules for protecting population from exposure to electromagnetic fields created by air transmission lines that transmit alternating current with industrial frequency. KODEKS: an electronic fund for legal and reference documentation. Available at: http://docs.cntd.ru/document/5200214 (09.08.2020) (in Russian).

${ }^{11}$ GOST 12.1.045-84. Electrostatic fields. Permissible levels at workplaces and requirements to control activities. KODEKS: an electronic fund for legal and reference documentation. Available at: http://docs.cntd.ru/document/9051575 (09.08.2020) (in Russian).
} 
to remember that current used for railways electrification has different properties in different countries. Thus, in the RF railways are electrified with direct current equal to 3,000 $\mathrm{W}$ and alternating current equal to $25 \mathrm{~kW} 50$ $\mathrm{Hz}$ and $25 \mathrm{~kW} \cdot 250 \mathrm{~Hz}$; in Europe, direct current equal to $1,500 \mathrm{~W}$ and alternating current equal to $15 \mathrm{~kW} 16^{2} / 3 \mathrm{~Hz}$; in the USA, alternating current equal to $11 \mathrm{~kW} 25 \mathrm{~Hz}$. Current may also have different properties depending on landscape peculiarities (for example, in pits). There is also specific electricity supply inside depots. All this makes it more difficult to perform comparative studies on impacts exerted by electromagnetic radiation on enginemen's bodies. Besides, we should bear in mind that exposure to electromagnetic radiation depends on an engine type.

In the RF electromagnetic field intensity, both as per its electric and magnetic component, was lower than MPL at all examined enginemen's workplaces. However, older engines (produced prior to 2008) tend to create electromagnetic fields with higher intensity than modern ones. We should note that greater electromagnetic field intensity is usually detected at electrified parts of railways [53]. Engine park modernization that is now being performed in the RF will allow decreasing electromagnetic field intensity in an engine cabin [54]. Similar technical solutions are also implemented abroad [55]. However, existing MPL for electromagnetic radiation do not take its cumulative effects into account. Therefore, there is still an open issue related to long-term exposure to electromagnetic field and its effects on health even if parameters of this field are within permissible levels [56].

We managed to find only one work where the authors stated that electromagnetic exposure caused elevated risks of heart rate disorders and sudden cardiac death [57].
However, this study was not a multi-centered one, and therefore, its results seem rather doubtful. Besides, according to our own data, an engine type (electric or diesel) does not influence risks of sudden cardiac death for enginemen or their assistants [58]. There are also works that focus on negative effects produced by alternating current on enginemen's immune system [59].

Another issue under discussion is influence exerted by electromagnetic fields on train passengers, railway bed repairmen, and people living in close proximity to railways [60, 61]. There was a 31-year study performed in Sweden; it revealed that electromagnetic exposure caused by railways might have cumulative effects thus resulting in higher risks of Alzheimer disease, myeloid leucosis, and Hodgkin lymphoma both among enginemen and railway beds repairmen [62, 63]. It was revealed that railway electrification system might influence operation of electric appliances located close to railways, in particular, electrocardiographs [64].

In our opinion, issues related to electromagnetic exposure being safe for enginemen's bodies have not been studied enough. It is unclear to what extent foreign experience in electromagnetic exposure regulation can be used in the RF due to currents with different properties used to electrify railways in our country and abroad. An open issue is also cumulative effects produced by electromagnetic exposure. Probably, standards for total exposure will have to be developed in future.

Microclimate in a cabin. Chemical factors. On international level microclimate inside an engine cabin is regulated by ISO 19659-1: $2017^{12}$ and ISO 19659-2: 2020 «Heating, ventilation and air conditioning systems for rolling stock» ${ }^{13}$. These regulatory

${ }^{12}$ ISO 19659-1:2017. Railway applications - Heating, ventilation and air conditioning systems for rolling stock - Part 1: Terms and definitions. ISO: International Organization for Standardization. Available at: https://www.iso.org/standard/65762.html (09.08.2020) (in Russian).

${ }^{13}$ ISO 19659-2:2020. Railway applications - Heating, ventilation and air conditioning systems for rolling stock - Part 2: Thermal comfort. ISO: International Organization for Standardization. Available at: https://www.iso.org/ru/standard/70232.html (09.08.2020) (in Russian). 
documents are partially reflected in GOST 33463.1-2015 «Life-support systems on railway rolling stock» ${ }^{14}$. Modern engine cabins are specifically designed to achieve maximum protection from exposure to temperature factor [65]. Studies that were performed in the $\mathrm{RF}$ and focused on microclimate inside engine cabins didn't reveal any deviations from existing standards. But still, most questioned engine team workers complain about uncomfortable temperature conditions inside an engine cabin [66]. We believe that most such complaints are rather subjective; still, we have to remember that exposure to too high or too low air temperature may result in lower working capacity, greater probability of an error, deterioration of engine team workers' health that will involve subsequent medical rehabilitation [67].

Visual loads caused by sleeper and infrastructure objects flickering, light from signal posts, lamps, etc., changes between night and daytime during a trip, moving through tunnels, are a microclimatic factor that is difficult to assess. For example, it was proven that bright sunlight or moving into and out of a tunnel created additional visual loads [68]. It was detected that visual organs of engine team workers were prone to elevated functional fatigue regardless of movement type, switching or main-line one [69]. Therefore, it is recommended to use prophylaxis aimed at preventing visual organs diseases in people who directly deal with train movement [70].

Modern engines are equipped with air cleaning systems; therefore, according to laboratory studies performed over 2012-2016, there was a decrease in air samples taken at enginemen's workplaces that deviated from hygienic standards as per chemicals MPC. However, air inside cabins still can't be completely purified from all the substances that come from outside. The most significant contaminants include nitrogen oxides, sulfur compounds, carbon oxides, hydrocarbons, as well as soot [71, 72]. Air contamination becomes especially acute issue in closed spaces, for example, tunnels [73]. However, total measurements of major contaminants revealed that effects produced by them on passengers, railway workers, and enginemen were negligible. It is due to small concentrations of pollutants, even inside tunnels [74].

We should note that domestic regulatory documents fix standards for microclimate inside engine cabins to a greater extent than for microclimate inside passenger carriages, as opposed to foreign regulation. We didn't manage to find any studies focusing on influence exerted by microclimate on health of passenger carriage workers. Probably, future works in the sphere will allow developing new approaches to microclimate standardization.

Conclusion. The Federal Law issued on December 27, 2002 No. 184-FZ «On technical regulation» ${ }^{15}$ made substantial alterations into legislative documents that regulated sanitaryepidemiologic aspects of railway traffic safety [75]. Most Russian regulatory documents are now in conformity with international practices. Overall, we should mention that Russian authors tend to pay much more attention to examining occupational risk factors and effects they produce on a human body whereas their foreign counterparts try to find solutions to health-related issues via various technical innovations.

There are still certain unresolved issues that require further investigation for regulation system development:

1. Most occupational risk factors are measured in standardized conditions. It is necessary to develop procedures for their measuring taking into account everyday peculiarities related to rolling stock operation.

\footnotetext{
${ }^{14}$ GOST 33463.1-2015. Life support systems on railway rolling stock. KODEKS: an electronic fund for legal and reference documentation. Available at: http://docs.cntd.ru/document/1200133110 (09.08.2020) (in Russian).

${ }^{15}$ On technical regulation: The Federal Law issued on December 27, 2002 No, 184-FZ. KODEKS: an electronic fund for legal and reference documentation. Available at: http://docs.cntd.ru/document/901836556 (09.08.2020) (in Russian).
} 
2. Exposure to occupational risk factors is limited with absolute values and probable accumulation of total exposure to an occupational factor is neglected. In case there is total exposure to a factor, time periods between shifts. That is, time when exposure is absent, are not taken into account or standardized.

3. Probable impacts on health exerted by under-threshold values of occupational risk factors are also neglected. Such effects are most likely to be related to total exposure accumulation.

4. It is necessary to further standardize exposure to occupational risk factors; first of all, in case there are no such procedures for them (visual loads, for example).

We hope that further development of legislative base for regulation over exposure to occupational risk factors and their effects on railway workers will allow improving their health and extending their active working life due to occupationally-induced diseases being successfully prevented.

Funding. The research was not granted any sponsor support.

Conflict of interests. The authors declare there is no any conflict of interests.

\section{References}

1. Plakhotnik V.N., Lakhnova J.V. Interaction of railway objects with the environment. Environmental Economics, 2002, no. 4, pp. 163-169.

2. Klochkova E.A. Okhrana truda na zheleznodorozhnom transporte [Labor protection provided for railway workers]. Moscow, Marshrut Publ., 2004, 412 p. (in Russian).

3. Samarskaya N.A. Analysis of the working conditions peculiarities and development of measures to ensure the metro workers safety. Ekonomika truda, 2019, vol. 6, no. 3, pp. 1271-1284 (in Russian).

4. Titova T.S., Kopytenkova O.I., Kurepin D.E. Acoustic impact assessment. Zheleznodorozhnyi transport, 2017, no. 5, pp. 75-77 (in Russian).

5. Kurmis A.P., Apps S.A. Occupationally-acquired noise-induced hearing loss: a senseless workplace hazard. Int J. Occup. Med. Environ. Health, 2007, vol. 20, no. 2, pp. 127-136. DOI: 10.2478/v10001-007-0016-2

6. Dobie R.A. The burdens of age-related and occupational noise-induced hearing loss in the United States. Ear. Hear., 2008, vol. 29, no. 4, pp. 565-577. DOI: 10.1097/AUD.0b013e31817349ec

7. Marushkina G.I., Mironova E.A., Plokhov V.N. Otsenka klinicheskoi i farmakoekonomicheskoi effektivnosti preparatov neiromediatornykh aminokislot $\mathrm{i}$ ingibitorov kholinesterazy $\mathrm{v}$ lechenii khronicheskoi sensonevral'noi tugoukhosti u rabotnikov zheleznodorozhnogo transporta [Assessing clinical and pharmaceutical-economic efficiency of neuromediator amino acids mediactions and choline esterase inhibitors in treating chronic sensorineural hearing loss among railway workers. Vestnik otorinolaringologii: materialy XI Rossiiskogo kongressa otorinolaringologov, 2012, no. 5, pp. 100-102 (in Russian).

8. Pankova V.B., Kaptsov V.A., Kas'kov Yu.N. Hygienic substantiation of risk of development of professional relative deafness at workers locomotive brigades. Byulleten' VSNTs SO RAMN, 2006, no. 3, pp. 38-41 (in Russian).

9. Vil'k M.F., Pankova V.B., Kaptsov V.A. Traffic noise as a risk factor for occupational deafness (exemplified by air and railway transport). Meditsina truda i promyshlennaya ekologiya, 2017, no. 9, pp. 36-37 (in Russian).

10. Girard S.A., Picard M., Davis A.C., Simard M., Larocque R., Leroux T., Turcotte F. Multiple work-related accidents: tracing the role of hearing status and noise exposure. Occup. Environ. Med., 2009, vol. 66, no. 5, pp. 319-324. DOI: 10.1136/oem.2007.037713

11. Nunes P.A.L.D., Travisi C.M. Rail noise-abatement programmes: a stated choice experiment to evaluate the impacts on welfare. Transport Reviews: A Transnational Transdisciplinary Journal, 2007, vol. 27, no. 5, pp. 589-604. DOI: 10.1080/01441640701322693

12. Arezes P.A., Miguel A.S. Hearing protection use in industry: the role of risk perception. Safety Science, 2005, vol. 43, no. 4, pp. 253-267. DOI: 10.1093/annhyg/mef067 
Regulation of work-related and occupational impacts on workers employed at railroads: experience gained ...

13. Virokannas H., Anttonen H., Niskanen J. Health risk assessment of noise, hand-arm vibration and cold in railway track maintenance. International Journal of Industrial Ergonomics, 1994, vol. 13, no. 3, pp. 247-252. DOI: 10.1016/0169-8141(94)90071-X

14. Ustinaviciene R., Piesine L. Morbidity of textile industry workers in Kaunas. Medicina, 2007, vol. 43, no. 6, pp. 495-500.

15. Ustinaviciene R., Obelenis V., Ereminas D. Occupational health problems in modern work environment. Medicina, 2004, vol. 40, no. 9, pp. 897-904.

16. Sliwinska-Kowalska M., Davis A. Noise-induced hearing loss. Noise Health, 2012, vol. 14, no. 61, pp. 274-280. DOI: 10.4103/1463-1741.104893

17. Kas'kov Yu.N. Deyatel'nost' upravleniya Rospotrebnadzora po zheleznodorozhnomu transportu [Activities performed by Rospotrebnadzor Railway Transport Office]. Zheleznodorozhnyi transport, 2019, no. 4, pp. 43-47 (in Russian).

18. Kryter K.D. Hearing loss from gun and railroad noise-relations with ISO standard. J. Acoust. Soc. Am., 1991, vol. 6, no. 90, pp. 3180-3195. DOI: 10.1121/1.401427.1999

19. Joynt J., Kang J. The influence of preconceptions on perceived sound reduction by environmental noise barriers. Science of the Total Environment, 2010, vol. 408, no. 20, pp. 4368-4375. DOI: 10.1016/j.scitotenv.2010.04.020

20. Nekrasiene R., Kucinskiene J. Formation of green areas of the Klaipedda city. Urban green formation. Science Jobs, 2011, vol. 1, no. 8, pp. 147-154 (in Russian).

21. Lie A., Skogstad M., Johnsen T.S., Engdahl B., Tambs K. Hearing status among Norwegian train drivers and train conductors. Occup. Med. (Lond), 2013, vol. 63, no. 8, pp. 544-548. DOI: 10.1093/occmed/kqt114

22. Lie A., Skogstad M., Johnsen T.S., Engdahl B., Tambs K. A cross-sectional study of hearing thresholds among 4627 Norwegian train and track maintenance workers. BMJ Open, 2014, vol. 16, no. 4 (10), pp. e005529. DOI: 10.1136/bmjopen-2014-005529

23. Rotter T. The noise factor in railway locomotives. Applied Ergonomics, 1982, vol. 13, no. 3, pp. 213-215. DOI: 10.1016/0003-6870(82)90014-x

24. Seshagiri B. Exposure to noise on board locomotives. AIHA J. (Fairfax, Va), 2003, vol. 5, no. 64, pp. 699-707. DOI: 10.1202/532.1.1

25. Igolkin A.A., Kryuchkov A.N., Lazutkin G.V., Afanasev K.M. The Study on Vibroacoustic Characteristics of Shunting Locomotive Cabin. Procedia Engineering, 2017, no. 176, pp. 724-731. DOI: $10.1016 /$ j.proeng.2017.02.320

26. Peng Y., Fan C., Hu L., Peng S., Xie P., Wu F., Yi S. Tunnel driving occupational environment and hearing loss in train drivers in China. Occup. Environ. Med., 2019, vol. 2, no. 76, pp. 97-104. DOI: 10.1136/oemed-2018-105269

27. Hahad O., Beutel M., Gori T., Schulz A., Blettner M., Pfeiffer N., Rostock T. [et al.]. Annoyance to different noise sources is associated with atrial fibrillation in the Gutenberg Health Study. Int. J. Cardiol., 2018, vol. 1, no. 264, pp. 79-84. DOI: 10.1016/j.ijcard.2018.03.126

28. Jarosińska D., Héroux M.È., Wilkhu P., Creswick J., Verbeek J., Wothge J., Paunović E. Development of the WHO Environmental Noise Guidelines for the European Region: An Introduction. Int. J. Environ. Res. Public. Health., 2018, vol. 20, no. 15 (4), pp. E813. DOI: 10.3390/ijerph15040813

29. Clark C., Paunovic K. WHO Environmental Noise Guidelines for the European Region: A Systematic Review on Environmental Noise and Cognition. Int. J. Environ. Res. Public. Health., 2018, vol. 7, no. 15 (2), pp. E285. DOI: 10.3390/ijerph15020285

30. Guski R., Schreckenberg D., Schuemer R. WHO Environmental Noise Guidelines for the European Region: A Systematic Review on Environmental Noise and Annoyance. Int. J. Environ. Res. Public. Health., 2017, vol. 8, no. 14 (12), pp. E1539. DOI: 10.3390/ijerph14121539

31. Grubliauskas R., Strukcinskiene B., Raistenskis J., Strukcinskaite V., Buckus R., Janusevicius T. Effects of urban rail noise level in a residential area. Journal of Vibroengineering, 2014, vol. 16, no. 2, pp. 987-996.

32. Lie A., Skogstad M., Johnsen T.S., Engdahl B., Tambs K. Noise-induced hearing loss in a longitudinal study of Norwegian railway workers. BMJ Open, 2016, vol. 2, no. 6 (9), pp. e011923. DOI: 10.1136/bmjopen-2016-011923 
33. Lie A., Skogstad M., Johnsen T.S., Engdahl B., Tambs K. The prevalence of notched audiograms in a cross-sectional study of 12,055 railway workers. Ear. Hear., 2015, vol. 36, no. 3, pp. e86-e92. DOI: 10.1097/AUD.0000000000000129

34. Riesco E., Munoz-Guijosa J.M. An enhanced whole-body vibration emission index for railway vehicles. Ergonomics, 2020, no. 11, pp. 1-11. DOI: 10.1080/00140139.2020.1776899

35. Samarskaya N.A., Il'in S.M. Ensuring safe working conditions and health protection of railway workers. Ekonomika truda, 2018, vol. 5, no. 4, pp. 1329-1345 (in Russian).

36. Ishchenko V.I. Uluchshenie uslovii i okhrany truda na zheleznodorozhnom transporte [Improvement of labor protection for workers employed at railways. Put' i putevoe khozyaistvo, 2005, no. 5, pp. 31-34 (in Russian).

37. Steina G.J., Múčkaa P., Gunstonb T.P., Badurac S. Modelling and simulation of locomotive driver's seat vertical suspension vibration isolation system. International Journal of Industrial Ergonomics, 2008, vol. 38, no. 5-6, pp. 384-395. DOI: 10.1016/j.ergon.2007.08.007

38. Tiemessen I.J.H., Hulshof C.T.J., Frings-Dresen M.H.W. Effectiveness of an occupational health intervention program to reduce whole body vibration exposure: an evaluation study with a controlled pretest-post-test design. Am. J. Ind. Med., 2009, vol. 52, no. 12, pp. 943-952. DOI: $10.1002 /$ ajim.20769

39. Johanning E., Landsbergis P., Fischer S., Christ E., Göres B., Luhrman R. Whole-body vibration and ergonomic study of US railroad locomotives. Journal of Sound and Vibration, 2006, vol. 298, no. 3, pp. 594-600. DOI: 10.1016/j.jsv.2006.06.030

40. Cooperridera N.K., Gordonb J.J. Shock and impact levels on North American locomotives. Journal of Sound and Vibration, 2008, vol. 318, no. 4-5, pp. 809-819. DOI: 10.1016/j.jsv.2008.04.042

41. Kolesnikov I.V., Pronnikov Yu.V. Experimental research of noise and vibration in cabins of locomotives. Vestnik Rostovskogo gosudarstvennogo universiteta putei soobshcheniya, 2011, vol. 43, no. 3, pp. 153-156 (in Russian).

42. Ohara H., Nakagiri S., Itani T., Wake K., Aoyama H. Occupational health hazards resulting from elevated work rate situations. J. Hum. Ergol. (Tokyo), 1976, vol. 5, no. 2, pp. 173-182.

43. Orlova N.V., Starokozheva A.Ya. Risk factors for cardiovascular disease among railway locomotive drivers. Meditsinskii alfavit, 2020, no. 2, pp. 37-40 (in Russian). DOI: 10.33667/20785631-2020-2-37-40

44. Birlik G. Occupational exposure to whole body vibration-train drivers. Ind. Health., 2009, vol. 47, no. 1, pp. 5-10. DOI: 10.2486/indhealth.47.5

45. Orlova N.V., Podzolkov V.I., Starokozheva A.Ya., Doldo N.M., Mironova E.V. Vitamin D deficiency study in railway drivers. Klinicheskaya laboratornaya diagnostika, 2020, vol. 65, no. 3, pp. 163-168 (in Russian).

46. Finagina E.A., Teodorovich O.V., Tsfasman A.Z., Shatokhin M.N., Shekhovtsov S.Yu. Testosterone level dependence on professional factors (on the example of locomotive drivers). Vestnik novykh meditsinskikh tekhnologii, 2017, vol. 24, no. 3, pp. 151-155 (in Russian).

47. Jalilian H., Zamanian Z., Gorjizadeh O., Riaei Z., Monazzam M.R., Abdoli-Eramaki M. Autonomic Nervous System Responses to Whole-Body. Int. J. Occup. Environ. Med., 2019, vol. 10, no. 4, pp. 174-184. DOI: 10.15171/ijoem.2019.1688

48. Zhang N., Fard M., Bhuiyan M.H.U., Verhagen D., Azari M.F., Robinson S.R. The effects of physical vibration on heart rate variability as a measure of drowsiness. Ergonomics, 2018, vol. 61, no. 9, pp. 1259-1272. DOI: 10.1080/00140139.2018.1482373

49. Landsbergis P., Johanning E., Stillo M., Jain R., Davis M. Occupational risk factors for musculoskeletal disorders among railroad maintenance-of-way workers. Am. J. Ind. Med., 2020, vol. 63, no. 5, pp. 402-416. DOI: 10.1002/ajim.23099

50. Sharp C., Woodcock J., Sica G., Peris E., Moorhouse A.T., Waddington D.C. Exposureresponse relationships for annoyance due to freight and passenger railway vibration exposure in residential environments. J. Acoust. Soc. Am., 2014, vol. 135, no. 1, pp. 205-212. DOI: 10.1121/1.4836115

51. Murakami Y., Yano T., Morinaga M., Yokoshima S. Effects of Railway Elevation, Operation of a New Station, and Earthquakes on Railway Noise Annoyance in Kumamoto, Japan. Int. J. Environ. Res. Public. Health., 2018, vol. 5, no. 15 (7), pp. 1417. DOI: 10.3390/ijerph15071417 
Regulation of work-related and occupational impacts on workers employed at railroads: experience gained ...

52. Gidlöf-Gunnarsson A., Ögren M., Jerson T., Öhrström E. Railway noise annoyance and the importance of number of trains, ground vibration, and building situational factors. Noise Health, 2012, vol. 4, no. 59, pp. 190-201. DOI: 10.4103/1463-1741.99895

53. Zal'tsman M.D., Tsygankov S.G., Tovasarov A.D., Konyrbaev R.T., Akberliev A.B. Analiz rezul'tatov attestatsii rabochikh mest AO «LOKOMOTIV» po usloviyam truda [Analysis of results obtained via assessing workplaces at «Lokomotiv» JSC as per working conditions]. Vestnik Kazakhskoi akademii transporta i kommunikatsii im. M. Tynyshpaeva, 2015, vol. 92, no. 1, pp. 10-17 (in Russian).

54. Kabantsev A.A. Nekotorye izmeneniya v konstruktsii elektrovozov 2ES5K «ERMAK» [Certain changes in construction of 2EC5K «ERMAK» electric locomotives]. Lokomotiv, 2017, vol. 721, no. 1, pp. 30-31 (in Russian).

55. Aerts S., Verloock L., Martens L., Joseph W. Compliance boundaries for train protection systems. Radiat Prot. Dosimetry., 2014, vol. 158, no. 1, pp. 68-72. DOI: 10.1093/rpd/nct183

56. Klimchenko L.N., Cherkasova T.S., Chubar' E.P. Prognozirovanie neblagopriyatnogo elektromagnitnogo vliyaniya na ob"ektakh zheleznodorozhnogo transporta [Predicting adverse electromagnetic impacts at railway transport objects]. Vestnik Rostovskogo gosudarstvennogo universiteta putei soobshcheniya, 2001, vol. 5, no. 1, pp. 126-129 (in Russian).

57. Santangelo L., Di Grazia M., Liotti F., De Maria E., Calabró R., Sannolo N. Magnetic field exposure and arrhythmic risk: evaluation in railway drivers. Int Arch Occup Environ Health, 2005, vol. 78, no. 4, pp. 337-341. DOI: 10.1007/s00420-004-0541-2

58. Zhidkova E.A., Naigovzina N.B., Kalinin M.R., Gutor E.M., Gurevich K.G. The Analysis of the Causes of Sudden Deaths among Workers of Locomotive Crews. Kardiologiya, 2019, no. 6, pp. 42-47 (in Russian).

59. Liu Y.M., Sun H.L., Luo Y., Dong Z.L., Ye W.S.Z. Influence of electric traction extremely low frequency electromagnetic field on immune function of train drivers. Bing. Za. Zhi., 2008, vol. 26, no. 11, pp. 659-660.

60. Aerts S., Plets D., Thielens A., Martens L., Joseph W. Impact of a small cell on the RF-EMF exposure in a train. Int. J. Environ. Res. Public. Health., 2015, vol. 27, no. 12 (3), pp. 2639-2652. DOI: $10.3390 /$ ijerph120302639

61. Niu D., Zhu F., Qiu R., Niu Q. Exposure to electromagnetic fields aboard high-speed electric multiple unit trains. J. Biol. Regul. Homeost. Agents, 2016, vol. 30, no. 3, pp. 727-731.

62. Röösli M., Lörtscher M., Egger M., Pfluger D., Schreier N., Lörtscher E., Locher P., Spoerri A., Minder C. Mortality from neurodegenerative disease and exposure to extremely lowfrequency magnetic fields: 31 years of observations on Swiss railway employees. Neuroepidemiology, 2007, vol. 28, no. 4, pp. 197-206. DOI: 10.1159/000108111

63. Röösli M., Lörtscher M., Egger M., Pfluger D., Schreier N., Lörtscher E., Locher P., Spoerri A., Minder C. Leukaemia, brain tumours and exposure to extremely low frequency magnetic fields: cohort study of Swiss railway employees. Occup. Environ. Med., 2007, vol. 64, no. 8, pp. 553-559. DOI: 10.1136/oem.2006.030270

64. Schlimp C.J., Breiteneder M., Seifert J., Lederer W. Interference of 16.7-Hz electromagnetic fields on measured electrocardiogram. Bioelectromagnetics, 2007, vol. 28, no. 5, pp. 402-405. DOI: $10.1002 /$ bem.20319

65. Khudonogov A.M., Volosatov S.N. K kontseptsii proektirovaniya system mikroklimata v kabine upravleniya lokomotivom [On a concept for designing microclimate systems in a locomotive cab]. Transportnaya infrastruktura Sibirskogo regiona, 2013, no. 2, pp. 352-357 (in Russian).

66. Serikov V.V., Zhidkova E.A., Kolyagin V.Ya., Zakrevskaya A.A., Bogdanova V.E. Social and psychologic, organizational factors influencing occupational activity of locomotive crew workers. Meditsina truda i promyshlennaya ekologiya, 2017, no. 7, pp. 17-21 (in Russian).

67. Dubilei G.S., Zaikina N.V. Professional'naya reabilitatsiya rabotnikov lokomotivnykh brigad [Occupational rehabilitation for engine team workers]. Cardio Somatika, 2013, no. S1, pp. 29 (in Russian). 
68. Byankina I.N., Panova I.E., Leonova E.S., Pavlenko O.A. Modern trends of ophthalmologic morbidity and visual health state in railway workers responsible for train control system. Permskii meditsinskii zhurnal, 2009, vol. 26, no. 6, pp. 127-131 (in Russian).

69. Leonova E.S., Byankina I.N., Shchekotov E.V., Karaulovskaya E.A. Results of deep clinical and physiologic study of eye in locomotive operators. Meditsina truda i promyshlennaya ekologiya, 2011, no. 1, pp. 38-42 (in Russian).

70. Leonova E.S. Mediko-sotsial'naya i ekonomicheskaya effektivnost' profilaktiki narushenii zreniya u mashinistov lokomotivov [Medical-social and economic efficiency of eye sight disorders prevention for enginemen]. Sbornik nauchnykh tezisov i statei «Zdorov'e i obrazovanie v XXI veke», 2011, vol. 13, no. 3, pp. 318-319 (in Russian).

71. Farkhatdinov G.A., Kas'kov Yu.N., Podkorytov Yu.I., Svitenko O.A. Aktual'nye voprosy obespecheniya sanitarno-epidemiologicheskoi bezopasnosti passazhirskikh i gruzovykh perevozok zheleznodorozhnym transportom Rossii [The actual problems of supply of sanitarium and epidemiological safety of passenger and goods trans-portation by Russian railways]. Dezinfektsiya. Antiseptika, 2014, vol. 5, no. 2, pp. 28-32 (in Russian).

72. Kas'kov Yu.N., Podkorytov Yu.I. The actual problems of supply of sanitarium and epidemiological safety of passenger and goods transportation by Russian railways. Meditsina truda i ekologiya cheloveka, 2016, no. 4, pp. 91-97 (in Russian).

73. Cha Y., Tu M., Elmgren M., Silvergren S., Olofsson U. Factors affecting the exposure of passengers, service staff and train drivers inside trains to airborne particles. Environ. Res., 2018, no. 166, pp. 16-24. DOI: 10.1016/j.envres.2018.05.026

74. Seaton A., Cherrie J., Dennekamp M., Donaldson K., Hurley J.F., Tran C.L. The London Underground: dust and hazards to health. Occup. Environ. Med., 2005, vol. 62, no. 6, pp. 355-362. DOI: $10.1136 /$ oem.2004.014332

75. Leksin A.G. Sanitary epidemiologic safety and technical regulations on railway transport. Meditsina truda i promyshlennaya ekologiya, 2009, no. 7, pp. 17-21 (in Russian).

Loginova V.A., Kas'kov Yu.N., Zhidkova E.A., Gurevich K.G., Smertina Yu.L., Pletnikova O.A. Regulation of work-related and occupational impacts on workers employed at railroads: experience gained in Russia and other countries. Health Risk Analysis, 2021, no. 1, pp.173-184. DOI: 10.21668/health.risk/2021.1.18.eng

Received: 08.02.2021

Accepted: 02.03.2021

Published: 30.03.2021 